\title{
EDUCAÇÃO, CIDADANIA E EMANCIPAÇÃO*
}

\author{
Susana VAsConcelos JimeneZ
}

$\mathcal{N}$

o repertório de visões que demarcam o campo sócio-educacional das últimas décadas, é evidente o foco central ocupado pela ressignificação da cidadania. O olhar cidadão espraiou-se por todas as esferas do cotidiano pedagógico e sócio-político, atraindo, para seu âmbito, teoricistas e ativistas de todas as causas.

Com efeito, a cidadania constitui-se ponto de encontro das pluralistas concepções postas a dialogar nos cursos de formação docente, de tal modo que pedagogias de diferentes tradiçôes, como taxionomias de distintas habilidades e competências, vêm desaguar no leito comum da formação para a cidadania. Não faria propósito, aqui, delongar-me sobre os chamados novos paradigmas educacionais, porém faço uma breve referência à formação do professor crítico-reflexivo. Nesse sentido, Isabel Alarcão, um dos nomes internacionais de destaque entre os defensores dessa proposta, endossa enfaticamente o ideário cidadão, postulando, quase a parafrasear Dewey em seu dictum imortal - "educação é vida, não preparação para a vida" -, que, à escola reflexiva, caberia, não só, preparar para o exercício da cidadania, mas, principalmente, "praticar e viver a cidadania". Assim, mesmo que se defina em favor de uma prática educativa "reflexiva e emancipadora", como assinala a autora, no livro Escola reflexiva e nova racionalidade, por ela organizado (Porto Alegre: ARTMED, 2001), o approach que contém tal paradigma elege a cidadania como o eixo

\footnotetext{
* Resenha do livro de Ivo Tonet (Ijuí: unijuí, 2005).

** Pós-doutora em Educação e professora da Universidade Estadual do Ceará (UFC). E-mail: susana_jimenez@uol.com.br
} 
nodal da propositura pedagógica, para, nos marcos do projeto democrático, aspirar à consecução de uma nova sociedade, genericamente idealizada como mais justa, mais ética, mais solidária.

Não obstante sua presença avassaladora em nosso meio, o construto que rubrica a conquista da cidadania como horizonte da prática pedagógica tem sido apenas excepcionalmente submetido à crítica entre os educadores, que, d'autrefois, se posicionam contrariamente aos paradigmas atrelados ao pressuposto da vigência de uma contemporânea sociedade do conhecimento, a exemplo daqueles comprometidos com o modelo de competências e as abordagens construtivistas. Nesse sentido, o livro do professor Ivo Tonet constitui-se um marco digno de nota.

No enfrentamento de um paradigma tão poderoso quanto renitente à análise desveladora dos seus fundamentos e implicaçôes, o autor empreende, com as armas da crítica marxista, ontologicamente perspectivada, o mais rigoroso combate teórico-ideológico ao conjunto multifacetado de lugares-comuns de maior ou menor grau de lisura ou refinamento acadêmico, os quais, quando não exprimem uma grosseira apologética, ignoram os limites que circunscrevem a cidadania à conquista de direitos políticos no escopo da ordem burguesa, tratando-a, erroneamente, como sinônimo de emancipação ou liberdade plena.

É bem verdade que o autor já vinha de longa data explorando, em suas raízes históricas, bem como em sua reedição contemporânea, as problemáticas relaçôes entre socialismo e democracia. Outros pensadores, com destaque para Chasin, amplamente citado por Tonet no conjunto de sua obra, também com grande pertinência, resgatam a crítica ontológica produzida por Marx sobre o complexo da política, reconhecendo, como Tonet, que as objetivaçôes afetas à democracia e à cidadania integram necessariamente - ainda que de modo contraditório e tensionado - a sociabilidade regida pelo capital.

No livro em foco, o autor retoma de forma aprofundada e com grande riqueza de elementos a crítica da emancipação política, "uma dimensão da existência atual, resultado - ainda em curso - do processo histórico" (p. 201), vis à vis a colocação da emancipação humana, uma forma de sociabilidade superior à primeira, uma vez que, "fundada na materialidade do trabalho associado, permite aos homens serem os verdadeiros senhores do seu destino" (p. 196). 
O mérito insuperável de Tonet consiste, contudo, de modo muito particular, em perscrutar à luz desse entendimento crítico o terreno da educação, vetando, a contrapelo do discurso dominante, o axioma que nivela cidadania e emancipação como o destino último da prática educativa; recuperando, ao mesmo tempo, o elo, perdido nos desvãos da esquerda pedagógica democrática, entre a educação emancipadora e a revolução socialista.

Com efeito, o comparecimento progressivo do ideário cidadão nas produções de pedagogos historicamente identificados com os interesses da classe trabalhadora vai se constituir na porta de entrada para a análise empreendida pelo autor. Assim, na Introdução do livro, este passa em revista os posicionamentos basilares de um conjunto significativo desses educadores, indagando sobre os fatores teórico-práticos que os teriam levado, a partir dos anos de 1980 no Brasil, a apagar de suas letras a articulação educação-revolução, em nome da vinculação educação-cidadania, desconsiderando que "a cidadania moderna tem sua base (...) no ato de compra e venda da força de trabalho e, por conseguinte, nenhum aperfeiçoamento, melhoria, ampliação, correção ou conquista de direitos que compõem a cidadania poderá eliminar a raiz que produz a desigualdade social" (p. 208). Reconhecido em sua devida complexidade, o fenômeno é remetido ao problema da desqualificação da estratégia revolucionária e da simultânea reenfatização da crença na democracia/via democrática para o socialismo, derivada de um complexo de objetivaçōes histórico-ontológicas que vão ser exploradas ao longo da obra.

De forma necessariamente breve, mas com irrepreensível densidade filosófica, o autor explicita os fundamentos - ontológicos, por certo - que ancoram sua investigação. Com base nesses elementos, indica, no Capítulo I, o movimento através do qual o ponto axial do pensamento sobre o real transitou historicamente da centralidade da objetividade à centralidade da subjetividade, uma e outra ideação, capengantes em sua capacidade de abranger a totalidade do ser, com o agravo, diga-se mais, representado pelo irracionalismo subjetivista das últimas décadas, que se expressa na "intensificação cada vez maior da fetichização da realidade e da consciência (...)" (p. 44), pari passu a "uma sempre maior afirmação da incapacidade do homem de compreender a realidade como totalidade e, por conseqüência, de intervir para transformá-la radicalmente" (p. 47). Nesse panorama, 
situa o autor o desvio idealista que atribui "à esfera da política [e, portanto, à democracia e à cidadania] a capacidade de instauração de uma sociedade livre e igualitária” (p. 47). Na última parte do capítulo, Tonet recupera os fundamentos marxianos, resgatados por Lukács, que superam a unilateralidade de ambos, o idealismo e o materialismo, permitindo, por um lado, a apreensão da objetividade como objetividade social (objetivação da subjetividade) e, por outro, tomando a realidade como resultado da atividade humana ontologicamente matizada pelo trabalho. Sobre esse alicerce, passa, nos demais capítulos, a tratar da cidadania sob a ótica liberal e da esquerda democrática, seguida da crítica marxiana da cidadania; da perspectiva marxiana da emancipação humana; e, finalmente, da relação entre emancipação humana e o complexo da educação.

Em seu percurso, o autor permanece rigorosamente apegado às articulações indissociáveis entre a consciência e os nexos da causalidade, repelindo das elaborações sobre o real suas estratégias e possibilidades de transformação, o espectro do voluntarismo e do empiricismo. Assim, ao denunciar o extravio teleológico de cunho subjetivista, hoje patente, professa que fatores causais concorreriam para um mais agudo "desnorteamento das subjetividades", ponderando, nesse sentido:

(...) de um lado, a razão está desaparelhada para apreender o processo real em curso (...); de outro lado, a própria realidade ainda está muito tumultuada e não poderia dar-se a conhecer de modo concreto, nem mesmo que a razão estivesse - por hipótese - adequadamente instrumentalizada. (p. 201)

Realçando, sob esse prisma, o caráter ao mesmo tempo alienante e superador da alienação da prática educativa na sociedade de classes, insere o complexo da educação no contexto da crise estrutural do capital, argumentando que o aprofundamento da barbárie social daí decorrente intensifica as contradiçôes entre a realidade e o discurso que sobre ela se produz e se apregoa, aí operando o falseamento do próprio conceito de emancipação, que passa a ser confundido "com o humanismo, a solidariedade, o desenvolvimento integral do homem e a participação cidadã e democrática” (p. 229).

Tonet culmina sua argumentação, estabelecendo os "requisitos gerais para uma ação educativa que tenha por objetivo contribuir para 
a emancipação humana” (p. 207). Ao avesso das exortações da ordem do dever-ser, tais requisitos são zelosamente problematizados, tendo em conta "a natureza da educação e as adversidades do momento presente" (p. 243), ao mesmo tempo em que se interconectam à tese, perseguida pelo autor, segundo a qual, ultrapassando os avanços significativos, porém necessariamente parciais, alcançados no âmbito da emancipação política, "a emancipação humana, (...) um momento histórico para além do capital, é que representa o espaço indefinidamente aperfeiçoável de uma autoconstrução humana plenamente livre" (p. 241).

O livro de Ivo Tonet oferece, em suma, um valioso suporte teórico para aqueles educadores que ousarem colocar/recolocar suas posiçóes teórico-práticas na trilha da radicalidade revolucionária, nesse momento tão crucial para a própria continuidade da história humana. 